\title{
The special responsibility of government lawyers and the Iraq inquiry
}

Article

Accepted Version

Windsor, M. (2019) The special responsibility of government lawyers and the Iraq inquiry. British Yearbook of International Law, 87 (1). pp. 159-176. ISSN 0068-2691 doi: https://doi.org/10.1093/bybil/bry025 Available at https://centaur.reading.ac.uk/79318/

It is advisable to refer to the publisher's version if you intend to cite from the work. See Guidance on citing.

To link to this article DOI: http://dx.doi.org/10.1093/bybil/bry025

Publisher: Oxford University Press

All outputs in CentAUR are protected by Intellectual Property Rights law, including copyright law. Copyright and IPR is retained by the creators or other copyright holders. Terms and conditions for use of this material are defined in the End User Agreement.

\section{www.reading.ac.uk/centaur}

\section{CentAUR}

Central Archive at the University of Reading

Reading's research outputs online 
THE SPECIAL RESPONSIBILITY OF GOVERNMENT LAWYERS AND THE IRAQ INQUIRY

By MATTHEW WINDSOR*

\section{INTRODUCTION}

The United Kingdom House of Commons endorsed the decision to invade and occupy Iraq on 18 March 2003. That morning, Elizabeth Wilmshurst - a deputy legal adviser at the Foreign and Commonwealth Office (FCO) - requested early retirement after almost 30 years of public service, because she regarded the intervention as unlawful without a United Nations Security Council resolution explicitly authorising the use of force. Despite her well-received testimony before the Iraq Inquiry, ${ }^{1}$ the Report of the Inquiry left the story of Wilmshurst's departure on the cutting room floor. With her decision to speak law to power erased from the official record, international law's heroine had been reduced to a bit part.

The absence of discussion of Wilmshurst's departure in the Report is emblematic of the Inquiry's limited coverage of the role of government lawyers in foreign ministries who advise on international law. In particular, the Report did not express a view on the government lawyer's so-called 'special responsibility', a conception of the advisory function introduced by FCO legal advisers during the Inquiry hearings. This article examines the scope of the government legal adviser's special responsibility, discussing the manner in which such a responsibility might be discharged before and after policy decision-making on the use of force.

The argument proceeds as follows. Section II canvasses the Report's restricted treatment of the FCO legal adviser's responsibilities, compared to its in-depth analysis of the role of the Attorney General. Section III considers an issue that the Report does not explore, and that advisers themselves relegate to the domain of individual conscience: the options available to an adviser after a policy decision is made, where their advice has not been accepted. Section IV asserts that the adviser's choice to either remain in post or resign in protest conditions their subsequent involvement in legal explanation for the use of force, with a direct bearing on the continued operation of their special responsibility. In an effort to 'make sense of inquiry sensemaking', ${ }^{2}$ Section V concludes by arguing that the lessons stipulated in the Report support a conception of the adviser's special responsibility that is exercisable rather than extinguished after a policy decision is reached.

\section{II. 'FAR FROM SATISFACTORY': LEGAL ADVICE IN THE IRAQ INQUIRY}

The Inquiry offered a unique opportunity to examine the content of legal advice, and the circumstances in which advice was provided to the UK government in the lead-up to a major military engagement. Ordinarily, the professional activities of government legal advisers belong to the 'secret life of international law', ${ }^{3}$ making it difficult to ascertain how international

\footnotetext{
* Lecturer in Public and International Law, University of Reading, United Kingdom. Email: m.r.windsor@reading.ac.uk. All URLs are correct as of 1 September 2018.

1 S Hoggart, 'Lioness gives Chilcot inquiry teeth' The Guardian (26 January 2010) <https://www.theguardian.com/uk/2010/jan/26/chilcot-iraq-inquiry-wilmshurst>; Mary Dejevsky, 'Wilmshurst: An ovation for witness of principle' The Independent on Sunday (31 January 2010) <https://www.independent.co.uk/news/uk/politics/wilmshurst-an-ovation-for-witness-of-principle1884541.html>.

2 A Brown, 'Making Sense of Inquiry Sensemaking' (2000) 37 Journal of Management Studies 45.

3 D Bethlehem, 'The Secret Life of International Law' (2012) 1 Cambridge Journal of International and Comparative Law 23, 29.
} 
law has been 'interpreted, applied, followed or ignored'. ${ }^{4}$ While the Inquiry's terms of reference were primarily focused on decision-making, ${ }^{5}$ Sir John Chilcot - the Chairman of the Inquiry-acknowledged that decisions are 'interlinked by a web of advice, discussion and debate'. ${ }^{6}$ Accordingly, the Inquiry prised open the bureaucratic black box to reveal the actors and institutions involved in the delivery of legal advice. The Inquiry assembled an impressive archive of witness statements and hearing transcripts from individuals involved in advice provision, and many official documents pertaining to advice were declassified and published on an exceptional basis. ${ }^{7}$

Although it did not express a view on the legality of the UK's decision to go to war, ${ }^{8}$ the Report was far from the whitewash that some pundits had predicted, providing a damning audit of decision-making within the Blair government. On pre-conflict strategy and planning, the Report concluded that 'diplomatic options had not been exhausted', and that 'military action was [not] the last resort'. ${ }^{9}$ In relation to legal advice, the Report considered that the 'circumstances in which it was ultimately decided that there was a legal basis for UK participation were far from satisfactory' ${ }^{10}$

\section{A. The Attorney General}

In reaching that conclusion, the Report zeroed in on the advisory conduct of Lord Peter Goldsmith, the then Attorney General. ${ }^{11}$ Under UK constitutional arrangements, the Attorney General is the 'ultimate and authoritative source of legal advice' on international law. ${ }^{12}$ As a government Minister, the Attorney General is a politically responsible lawyer, whose advice has a 'special quality and status'. ${ }^{13}$ Prior to the Iraq invasion, it was widely accepted within the UK government that the Attorney General's legal clearance would be required before military force could be deployed. ${ }^{14}$

The central legal issue concerned the interpretation of Security Council resolution 1441, specifically whether a further determination by the Security Council was required before force could be used to secure Iraq's compliance with its disarmament obligations. The Attorney General initially considered that a second Security Council resolution would be necessary to authorise the use of force, only to later reach a different view that resolution 1441 could revive

\footnotetext{
${ }^{4}$ A Carty, 'The Practice of International Law' in D Armstrong (ed), Routledge Handbook of International Law (Routledge 2009) 81, 98.

${ }^{5}$ The Report of the Iraq Inquiry (Report of a Committee of Privy Counsellors), 6 July 2016, vol 1, Introduction, para 6. All sections of the Report are available at <http://webarchive.nationalarchives.gov.uk/20171123122743/http://www.iraqinquiry.org.uk/the-report>.

${ }^{6}$ House of Commons Foreign Affairs Committee, 'Progress of the Iraq Inquiry' (HC 1027), transcript of evidence given by Sir John Chilcot, 4 February 2015, Q1 <http://data.parliament.uk/writtenevidence/committee evidence.svc/evidencedocument/foreign-affairs-committee/progress-of-the-iraq-inquiry/oral/17950.html >.

${ }^{7}$ Report, vol 1, Introduction, paras 73-84 (discussing waiver of legal professional privilege and the Law Officers' Convention).

${ }^{8}$ Report, vol 1, Introduction, para 99.

${ }^{9}$ Report, vol 6, Section 7, para 331.

${ }^{10}$ Report, vol 6, Section 7, para 384.

${ }^{11}$ Report, vol 5, Section 5.

${ }^{12}$ A Watts, 'International Law and International Relations: United Kingdom Practice' (1991) 2 EJIL 157, 159.

${ }^{13}$ T Daintith and A Page, The Executive in the Constitution: Structure, Autonomy and Internal Control (OUP 1999) 297.

${ }^{14}$ Transcript of evidence given by the Rt Hon Tony Blair, 29 January 2010, <http://webarchive.nationalarchives.gov.uk/20171123122254/http://www.iraqinquiry.org.uk/media/229766/201 0-01-29-transcript-blair-s1.pdf>, 150 (if the Attorney "in the end had said, "This cannot be justified lawfully", we would have been unable to take action').
} 
an earlier authorisation without the need for additional Security Council input (the 'revival argument'). ${ }^{15}$

While it did not pronounce on the substantive merits of the revival argument, the Report's forensic narration of the Attorney General's advisory about-face demonstrates how law can be made to 'fit around policy, rather than the other way round'. ${ }^{16}$ The Report sustains a strong inference that the Attorney General had been placed under considerable pressure to produce advice that corresponded with preordained foreign policy priorities. He had asked to be kept 'in the loop from a very early stage' as policy was formulated about Iraq, so that he would not be 'presented at the last moment with a request for a "yes or no" answer'. ${ }^{17}$ However, a decision was taken to "delay the receipt of formal advice from the Attorney'. ${ }^{18}$ The Attorney General ultimately advised that there was a secure legal basis for action a mere seven days before the commencement of Operation Iraqi Freedom. ${ }^{19}$ The Report concluded that Prime Minister Tony Blair and Foreign Secretary Jack Straw should have invited the Attorney to advise on the 'legal implications under discussion at key stages in the development of resolution 1441', to ensure that 'policy discussions were fully informed by consideration of legal issues'. ${ }^{20}$

\section{B. FCO legal advisers}

Although the Attorney General was tasked with providing the 'decisive legal opinion', ${ }^{21}$ the cadre of legal advisers at the FCO have long been the repository of specialist international law knowledge and expertise within the UK public service. ${ }^{22}$ Legal advisers in foreign ministries are tasked with fostering a 'culture of law-abidingness' in executive government, ${ }^{23}$ and have been described as 'among those individuals most committed to promoting respect for international law'. ${ }^{24}$ In the UK, the 'close relationship' between the Attorney General and FCO legal advisers is a vital component of the constitutional machinery for ensuring that the government complies with international law. ${ }^{25}$

The preliminary view of Sir Michael Wood, the FCO legal adviser, was that the UK 'wouldn't have a leg to stand on' if it sought to rely on the revival argument, rather than procuring a further Security Council resolution. ${ }^{26}$ On several occasions, Wood proactively provided legal advice to this effect, reflecting a FCO tradition that lawyers 'don't wait to be

\footnotetext{
${ }^{15}$ Report, vol 5, Section 5, para 107. See also Henderson in this Symposium.

${ }^{16}$ P Sands, 'A Grand and Disastrous Deceit' (London Review of Books, 28 July 2016) 9.

${ }^{17}$ Report, vol 1, Section 3.2, para 347.

${ }^{18}$ Report, vol 5, Section 5, para 903.

${ }^{19}$ Report, vol 6, Section 7, para 385.

${ }^{20}$ Report, vol 2, Section 3.5, paras 985-86. See now Cabinet Office, Ministerial Code (January 2018) 6 (the Attorney must be 'consulted in good time before the Government is committed to critical decisions involving legal considerations').

${ }^{21} \mathrm{M}$ Weller, Iraq and the Use of Force in International Law (OUP 2010) 247.

${ }^{22}$ I Sinclair, 'The Practice of International Law: The Foreign and Commonwealth Office' in B Cheng (ed), International Law: Teaching and Practice (Stevens 1982).

${ }^{23}$ F Berman, 'Conclusion' in A Zidar and J-P Gauci (eds), The Role of Legal Advisers in International Law (Brill 2016) 384.

${ }^{24} \mathrm{~K}$ Annan in United Nations Office of Legal Affairs, Collection of Essays by Legal Advisers of States, Legal Advisers of International Organizations and Practitioners in the Field of International Law (United Nations 1999) ix.

${ }^{25}$ Statement by Sir Michael Wood, 15 January 2010,

<http://webarchive.nationalarchives.gov.uk/20171123123923/http://www.iraqinquiry.org.uk/media/95994/2010

-01-15-Statement-Wood-1.pdf>, para 8 (hereafter 'Wood Statement, 15 January 2010').

${ }^{26}$ Report, vol 1, Section 3.2, para 294.
} 
asked' to ensure that senior officials accurately understood the legal position. ${ }^{27}$ For instance, after the passage of resolution 1441, Straw commented on the UK proceeding with military action in the event that a second resolution was not obtained - an idea which, from Wood's perspective, was 'so completely wrong' that he regarded it as necessary to draw the correct position to Straw's attention. ${ }^{28}$ In the exchange that ensued, ${ }^{29}$ Straw responded: 'I note your advice, but I do not accept it'. ${ }^{30}$

Concerned about this apparent 'rebuke' to Wood for expressing his view, ${ }^{31}$ the Attorney General wrote to Straw about the role of FCO legal advisers in the following terms: ${ }^{32}$

[i]t is important for the Government that its lawyers give advice which they honestly consider to be correct ... $[T]$ hey should give the advice they believe in, not the advice which they think others want to hear. To do otherwise would undermine their function ... in giving independent objective and impartial advice ... [I]f a government legal adviser genuinely believes that a course of action would be unlawful, then it is his or her right and duty to say so.

In one of its only evaluative remarks on the role of FCO legal advisers, the Report regarded the Attorney General's insistence on the duty of advisers to offer 'frank, honest and, if necessary, unwelcome legal advice, without fear of rebuke from Ministers, [as] timely and justified'. ${ }^{33}$ This reflects the professional ethics orthodoxy that lawyers in their capacity as advisers must offer their candid view about what the law requires, 'even if the news frustrates or infuriates the client'. ${ }^{34}$

\section{Whither special responsibility?}

The Report did not directly link its discussion of advisory conduct to the government lawyer's 'special responsibility' in the context of international law, a concept advanced by Wood and Wilmshurst during the Inquiry hearings. For Wood, it follows from the 'special nature' of the international legal system that the role of the legal adviser will be 'somewhat special'. ${ }^{35}$ Distinctive features of the international legal system include the absence of a court with compulsory jurisdiction, and the adviser's direct involvement in the development of customary international law through state practice. ${ }^{36}$

Where there is no judge over the adviser's shoulder, ${ }^{37}$ Wood asserted that the adviser has a 'special responsibility' to 'ensure that the law is upheld'. ${ }^{38}$ Wilmshurst considered that the 'special responsibility' requires the adviser to be 'more cautious about trying to keep within

\footnotetext{
27 Transcript of evidence given by Sir Michael Wood, 26 January 2010, <http://webarchive.nationalarchives.gov.uk/20171123122957/http://www.iraqinquiry.org.uk/media/95218/2010 -01-26-Transcript-Wood-S1.pdf>, 7-8 (hereafter 'Wood Evidence, 26 January 2010').

${ }^{28}$ Ibid, 31 .

${ }^{29}$ For a detailed discussion, see Aalberts and Boer in this Symposium.

${ }^{30}$ Report, vol 5, Section 5, para 351.

${ }^{31}$ Ibid, para 363.

32 Ibid, para 357.

${ }^{33}$ Ibid, para 377.

${ }^{34}$ D Luban, 'A Different Nightmare and a Different Dream' in Legal Ethics and Human Dignity (CUP 2009) 154.

${ }^{35}$ M Wood, 'Legal Advisers' in R Wolfrum (ed), Max Planck Encyclopaedia of Public International Law (OUP 2006-, online edition [www.mpepil.com]), [16].

${ }^{36}$ Ibid, [19].

37 UK Government Legal Department, Judge Over Your Shoulder: A Guide to Good Decision Making (Government Legal Department 2016).

38 Wood Statement, 15 January 2010, para 37.
} 
the law, not less' ${ }^{39}$ Rather than regarding the 'reasonable case' standard adopted by the Attorney General as a sufficient legal basis for taking military action, ${ }^{40}$ the adviser's special responsibility necessitates a 'higher degree of legal certainty'. ${ }^{41}$ Recognition of a special responsibility reflects an awareness that there may be no 'safety net' other than the adviser's 'care, integrity and good faith' against advice which might 'subvert or erode the international legal order'. ${ }^{42}$

\section{SHOULD I STAY OR SHOULD I GO?}

How did FCO legal advisers respond when their views regarding the illegality of military action without a further Security Council resolution conflicted with the Attorney General's endorsement of the revival argument? Although the Report did not deal with the matter, the Inquiry archive permits an interpretive reconstruction of the choice calculus for advisers after a decision contrary to their preferred legal analysis was reached. ${ }^{43}$ While their legal analysis had been identical prior to the Attorney General's delivery of legal advice, Wood chose to remain in post, while Wilmshurst departed her office.

\section{A. A conscience call}

Both Wood and Wilmshurst regarded resolution of the 'should I stay or should I go' conundrum as within the province of conscience. In her letter requesting early retirement, Wilmshurst asserted that she could not 'in good conscience' go along with the decision to invade Iraq. ${ }^{44}$ Before the Inquiry, Wilmshurst described the decision to leave a job as an 'enormously personal matter', ${ }^{45}$ while Wood regarded 'questions of conscience' as 'very individual questions' ${ }^{46}$ This mirrors a broader tendency to frame departure from public office in highly individualistic terms, as the 'last refuge of personal responsibility', ${ }^{47}$ or as a way in which to vindicate one's honour or moral integrity. ${ }^{48}$ After the Report's release, Chilcot's telling concession that he was 'not an ethicist' reveals why the Inquiry may have declined to venture a view as to whether staying or going was the preferable advisory response. ${ }^{49}$

\footnotetext{
${ }^{39}$ Transcript of evidence given by Ms Elizabeth Wilmshurst, 26 January 2010, <http://webarchive.nationalarchives.gov.uk/20171123123029/http://www.iraqinquiry.org.uk/media/95214/2010 -01-26-Transcript-Wilmshurst-S3.pdf>, 9 (hereafter 'Wilmshurst Evidence, 26 January 2010').

${ }^{40}$ Report, vol 5, Section 5, para 560.

${ }^{41}$ Wood Statement, 15 January 2010, paras 30, 36; M Wood, 'International Law and the Use of Force: What Happens in Practice?’ (2013) 53 Indian Journal of International Law 345, 348-49.

${ }^{42}$ Report of the Joint Committee Established by the American Society of International Law and the American Branch of the International Law Association, 'The Role of the Legal Adviser of the Department of State' (1991) 85 AJIL 358, 361 (hereafter 'ASIL-ILA Joint Committee Report').

${ }^{43} \mathrm{C}$ Peevers, 'The Chilcot Inquiry-The Publication Saga of an Official History' (Opinio Juris, 17 February 2015 ) <http://opiniojuris.org/2015/02/17/guest-post-chilcot-inquiry-part-publication-saga-official-history>.

44 'Wilmshurst resignation letter' (BBC News, 24 March 2005)

<http://news.bbc.co.uk/2/hi/uk_news/politics/4377605.stm> (hereafter 'Wilmshurst resignation letter').

${ }^{45}$ Wilmshurst Evidence, 26 January 2010, 23.

${ }^{46}$ Wood Evidence, 26 January 2010, 64. See also Wood in this Symposium ('In my view this is not a matter on which one can generalize. Each case is objectively and subjectively different; the facts will differ, as will the circumstances of the particular individual').

${ }^{47}$ D Thompson, 'Ascribing Responsibility to Advisers in Government' (1983) 93 Ethics 546, 558.

${ }^{48}$ WF Felice, How Do I Save My Honor? War, Moral Integrity and Principled Resignation (Rowman \& Littlefield 2009); C Hatier, 'The Virtues and Vices of Resigning from Office' (2016) 44 Policy \& Politics 351.

49 'Iraq Inquiry: Full transcript of Sir John Chilcot's BBC interview' (BBC News, 6 July 2017)

<http://www.bbc.com/news/uk-politics-40510539>.
} 
Positing the adviser's choice as a conscience call is questionable to the extent that the classification purports to oust further scrutiny. ${ }^{50}$ Martti Koskenniemi has recently critiqued the 'translation of social problems into issues of individual consciences ... [which] ignore[s] the way those consciences are produced by historical and institutional structures, systems of knowledge and practice'. ${ }^{51}$ Significantly, neither Wood nor Wilmshurst connected this choice to the special responsibility they advocated elsewhere. This carries the implication that the special responsibility pertains primarily to the pre-decision phase of policy formation, with post-decision advisory choices apparently resolved according to personal temperament. ${ }^{52}$

To counter the privative effect of invoking conscience, an alternative conception foregrounds conscience's relational or communal dimensions. ${ }^{53}$ This was the insight offered by Michael Walzer, in the context of heated debates about the legitimate bases for conscription during the Vietnam War. ${ }^{54}$ Walzer criticised justifications for conscientious objection that were grounded on appeals to conscience, to the extent that their individualist premises downplayed the 'collective and pluralist nature of political conscience-formation' ${ }^{55}$ Instead, for Walzer, the word conscience implied a 'shared moral knowledge', developed not in isolation but through interaction with other citizens and engagement in a variety of groups and associations. ${ }^{56}$ Thus, conscientious objectors did not act according to 'merely personal' codes, but based on 'shared principles and mutual engagements', as part of a wider community with 'some degree of responsibility, mutuality and social discipline' ${ }^{57}$

\section{$B$. The requirements of role}

Transposing Walzer's observations regarding the communal dimensions of conscience to the professional situation of legal advisers yields an important but underappreciated insight: that the choices advisers face after policy decision-making are not solely a matter of personal preference, but are intimately linked to the interests and ideals they are tasked with serving in the performance of their professional role. That government lawyers advising on international law might share a communal identity — with 'shared principles and mutual engagements' 58

50 See A Giubilini, 'Conscience' Stanford Encyclopedia of Philosophy (Winter 2016 Edition) $<$ https://plato.stanford.edu/archives/win2016/entries/conscience> ('[A]ppeals to conscience often replace reason giving and are made with the expectation that no further reason for one's decisions and positions is requested'); $\mathbf{J}$ Childress, 'Appeals to Conscience' (1979) 89 Ethics 315, 329 (when an agent appeals to her conscience, '[u]sually the agent has given up the attempt to convince others of the objective rightness of his act and is content to assert its subjective rightness').

51 M Koskenniemi, 'To Enable and Enchant - On the Power of Law' in W Werner et al (eds), The Law of International Lawyers: Reading Martti Koskenniemi (CUP 2017) 393, 402.

52 T Kelly, 'Beyond Ethics: Conscience, Pacifism and the Political in Wartime Britain' (2018) 8 HAU: Journal of Ethnographic Theory 114, 125 ('conscience can work as a tightly circumscribed form of objection that personalizes opposition and marks out a very narrow space for debate and dissension').

${ }^{53}$ P Strohm, Conscience: A Very Short Introduction (OUP 2011) 9 (discussing the etymology of conscience as knowledge held 'together with' or 'in common'). See also TR Burns and E Engdahl, 'The Social Construction of Consciousness. Part 1: Collective Consciousness and its Socio-Cultural Foundations' (1998) 5 Journal of Consciousness Studies 72; RK Vischer, Conscience and the Common Good (CUP 2009); TL Brownlee, 'The Sociality of Conscience and Rawls' Liberalism' in CA Speight and M Zank (eds), Politics, Religion and Political Theology (Springer 2017) 75; JJ Howard, Conscience in Moral Life: Rethinking How Our Convictions Structure Self and Society (Rowman \& Littlefield 2014).

${ }^{54}$ M Walzer, Obligations: Essays on Disobedience, War, and Citizenship (Harvard University Press 1970).

${ }^{55}$ K Forrester, 'Citizenship, War, and the Origins of International Ethics in American Political Philosophy, 19601975’ (2014) 57 Historical Journal 773, 785.

${ }^{56}$ Walzer, Obligations, 5.

57 Ibid.

58 Ibid. 
was recognised by Wilmshurst, when she quipped that, although the Foreign Secretary was a lawyer, he was not an 'international lawyer'. ${ }^{59}$ Despite their invocation of conscience, Wood and Wilmshurst tacitly appealed to distinct understandings of the requirements of the advisory role.

Wood's decision to remain in post was predicated on a conviction that the adviser's role changes once a decision is taken. Before the Inquiry, Wood described advisers as having two functions: 'to give advice before a decision; [and] to defend the position after the decision' ${ }^{60}$ In other words, a line in the sand is drawn at the point of decision between 'fearless advice' and 'loyal implementation'. ${ }^{61}$ This approach corresponds with Max Weber's classic account of the ethos of bureaucratic office. For Weber, if a superior insists on a policy, it is the bureaucrat's 'duty and even his honour to carry it out as if it corresponded to his innermost conviction'. ${ }^{62}$ The Weberian approach to public administration commands widespread adherence in civil service and diplomatic traditions. ${ }^{63}$ For example, according to Sir Michael Quinlan: ${ }^{64}$

[o]ne may think a particular policy concept to be a square circle, and indeed within the confidence of Whitehall one may argue fervently to that effect, but once the decision is taken, it is a matter not just of duty but of professional pride to help make the very best square circle that effort and imagination can contrive.

While Wilmshurst acknowledged that it is the duty of civil servants to implement policy decisions, she considered that they have the option to leave their job if they object to the nature of their assignments. ${ }^{65}$ Although resignation is regarded as a wholly disproportionate response in most situations where government employees disagree with policy decisions, a number of advisers and commentators have offered their view on the circumstances in which resignation is appropriate, desirable or even necessary. A former legal adviser to the US State Department argued that advisers should resign when the government refuses to follow advice that they regard as 'essential'. ${ }^{66}$ Advisers should not be 'compliant handmaiden[s]' in situations where the government wants to take the country to 'hell in a handbasket', ${ }^{67}$ and they should never knowingly assist illegal conduct or instruct their government on how to violate the law. ${ }^{68}$

\section{Exit, voice and loyalty}

Albert Hirschman's famous discussion of exit, voice and loyalty offers an illuminating rubric through which to analyse the alternative choices available to advisers. ${ }^{69} \mathrm{He}$ argued that employees who disagree with organisational policy and decision-making have three options

\footnotetext{
${ }^{59}$ Wilmshurst Evidence, 26 January 2010, 8.

${ }^{60}$ Wood Evidence, 26 January 2010, 34.

${ }^{61}$ J-P Gauci and K Jones, 'Conference Report: The Role of Legal Advisers in International Law' in A Zidar and J-P Gauci (eds), The Role of Legal Advisers in International Law (Brill 2016) 371, 373.

${ }^{62} \mathrm{M}$ Weber, Economy and Society (University of California Press 1978) 1404.

${ }^{63} \mathrm{H}$ Nicholson, Diplomacy (OUP 1969) 81 ('if advice is rejected by the Minister, it is 'the duty and function of the civil service to execute his instructions without further question').

${ }^{64}$ M Quinlan, 'Ethics in the Public Service' (1993) 6 Governance 538, 554.

${ }^{65}$ Wilmshurst Evidence, 26 January 2010, 24.

${ }^{66}$ C Harper in MP Scharf and PR Williams, Shaping Foreign Policy in Times of Crisis: The Role of International Law and the State Department Legal Adviser (CUP 2010) 213.

${ }^{67}$ MS Paulsen, 'Hell, Handbaskets and the Government Lawyer: The Duty of Loyalty and its Limits' (1998) 61(1) Law and Contemporary Problems 83, 106.

${ }^{68}$ R St J MacDonald, 'The Role of the Legal Adviser of Ministries of Foreign Affairs' (1977) 156 Recueil des Cours 385, 386.

69 A Hirschman, Exit, Voice and Loyalty: Responses to Decline in Firms, Organizations, and States (Harvard University Press 1970).
} 
available to them: exit (leaving the organisation); voice (attempting to change the policy from within); and loyalty (remaining in post). For Hirschman, exit, voice and loyalty were not mutually exclusive alternatives ${ }^{70}$ and he was intently focused on their various permutations. ${ }^{71}$

In a highly germane discussion of 'public goods', Hirschman observed that an individual's response to foreign policy decision-making might be affected by special responsibilities due to the communities they inhabit, which have the effect of modifying the choice calculus. ${ }^{72}$ He provided a suggestive discussion of how exit and loyalty might be supplemented by voice in the context of foreign policy: by working from within, in the case of loyalty; and by resigning in protest, in the case of exit.

Hirschman considered that loyalty often flourishes in organisations producing public goods, serving the 'socially useful purpose of preventing deterioration from becoming cumulative'. ${ }^{73}$ A fear that the organisation might 'go from bad to worse if they left' keeps the 'quality-conscious' member in post ${ }^{74}$ removing the possibility of their replacement by the 'wrong-headed or the less-competent' ${ }^{75}$ Loyalty is predicted to result in the member's ability to work from within as an agent of change, based on a conviction that 'persistence will pay off in future influence'. ${ }^{76}$

If a member opts for exit rather than loyalty where public goods are implicated, Hirschman cautioned that quiet withdrawal was not acceptable. He admonished members who exit without voice, presenting their choice in personal terms rather than publicly articulating the substantive reasons for their disagreement with policy decision-making. ${ }^{77}$ Instead, Hirschman recommended that members resign in protest, combining 'walking' with 'talking'. ${ }^{78}$

\section{THE POLITICS OF EXPLANATION}

The following section examines the ramifications of Wood's loyalty and Wilmshurst's exit in a key advisory practice setting after policy decisions have been made-legal explanation for the use of force- drawing on Hirschman's seminal account of working from within and resignation in protest.

Although there is no formal requirement to give reasons, recourse to force by states is increasingly accompanied by a public explanation for the legal basis of their actions. ${ }^{79}$ The legal explanation for the UK's use of force in Iraq was provided in the Attorney General's presentation of the legal position to Cabinet and Parliament on 17 March 2003. The Attorney General set out his 'view' of the legal basis for military action in a Written Answer to a Parliamentary Question in the House of Lords. A 'Foreign Office' memorandum was produced in support of the Written Answer, albeit largely authored by a team of lawyers external to the

\footnotetext{
${ }^{70}$ J Adelman, Worldly Philosopher: The Odyssey of Albert O. Hirschman (Princeton University Press 2013 ) 443.

${ }^{71}$ For a taxonomy of eight options, see L Seidman, 'Powell's Choice: The Law and Morality of Speech, Silence and Resignation by High Government Officials' in A Sarat (ed), Speech and Silence in American Law (CUP 2010).

${ }^{72}$ Hirschman, Exit, Voice and Loyalty, 100-101.

${ }^{73}$ Ibid, 79.

${ }^{74}$ Ibid, $98,79$.

75 JC Thomson, 'Getting Out and Speaking Out' (1974) 13 Foreign Policy 49, 51.

${ }^{76}$ Arnold Meltsner, Rules for Rulers: The Politics of Advice (Temple University Press 1990) 143.

${ }^{77}$ Hirschman, Exit, Voice and Loyalty, 105.

${ }^{78}$ See generally E Weisband and T Franck, Resignation in Protest: Political and Ethical Choices Between Loyalty to Team and Loyalty to Conscience in American Public Life (Penguin 1976); J Kirkpatrick, The Virtues of Exit: On Resistance and Quitting Politics (University of North Carolina Press 2017).

${ }^{79}$ C Peevers, The Politics of Justifying Force: The Suez Crisis, the Iraq War, and International Law (OUP 2013); D Kritsiotis, 'Theorising International Law on Force and Intervention' in A Orford and F Hoffmann (eds), The Oxford Handbook of the Theory of International Law (OUP 2016) 655.
} 
FCO. In its brevity, the Written Answer resembled the 'yes or no' answer that the Attorney General had earlier disavowed, failing to explain the legal basis for the conclusion that Iraq had not taken the 'final opportunity' to comply with its disarmament obligations. ${ }^{80}$ Meanwhile the 'Foreign Office' memorandum conveyed an opinion diametrically opposed to the advice offered earlier by FCO legal advisers.

The Report concluded that the Attorney General should have provided written advice that explained the legal basis on which the UK could take military action and set out the risks of legal challenge, on the basis that 'public support and understanding for a major military operation are essential'. ${ }^{81}$ But what of Wood's and Wilmshurst's involvement in legal explanation?

\section{A. Wood: advocacy mode}

Before a decision was reached, Wood had advised tirelessly that the UK would need to be satisfied that there was a proper legal basis in the event of military action, and that what the UK said 'publicly would need to be consistent with that legal basis'. ${ }^{22}$ Yet by remaining in post, Wood joined the team of lawyers who assisted the Attorney General in preparing the Written Answer and the 'Foreign Office' memorandum to deploy publicly in support of the government's position. Before the Inquiry, Wood observed that he was 'more or less on the sidelines' in the team because his views were well-known, although he 'read through the drafts' and made 'editorial suggestions' ${ }^{83}$ He clarified that he 'quickly moved on to other matters', and did not find himself having to 'defend this legal decision at great length or in a personal way thereafter', 84

Wood justified this involvement-however negligible - on the basis that, after the policy decision, the adviser shifts to 'advocacy mode', which deals with how a policy decision is 'presented in public'. ${ }^{85}$ Advocacy mode is consonant with a conception of the adviser's role that mandates switching hats to loyal implementation after a decision is made. In advocacy mode, as was the case here, advisers may be required to offer legal rationalisations for policy decisions they had earlier advised against. ${ }^{86}$ It involves advisers offering the best legal case in support of a policy, ${ }^{87}$ and stacking up 'ammunition' to defend it. ${ }^{88}$

Setting aside the specific circumstances of Wood's involvement, the adviser's entry into advocacy mode corresponds to the adviser's so-called 'duty to explain' ${ }^{89}$ Formulated by Harold Koh - the former legal adviser to the US State Department - the duty to explain involves the justification in a legal vernacular of the policy decision that is reached. Koh clarifies that when a 'final policy decision has been made and deemed lawful within the executive branch for a particular set of reasons, prompt disclosure of that legal analysis should be the norm' ${ }^{90}$ The duty to explain does not encompass public disclosure of the actual legal advice that the government received. ${ }^{91}$

\footnotetext{
${ }^{80}$ Report, vol 5, Section 5, para 2.

${ }^{81}$ Report, vol 6, Section 7, paras 423, 434.

${ }^{82}$ Report, vol 2, Section 3.3, para 85.

${ }^{83}$ Wood Evidence, 26 January 2010, 59-60.

${ }^{84}$ Ibid, 63.

85 Ibid, 60.

${ }^{86}$ HCL Merillat (ed), Legal Advisers and Foreign Affairs (Oceana Publications 1964) 18.

${ }^{87}$ ASIL-ILA Joint Committee Report, 362.

${ }^{88}$ JL Foster, 'An Advocate Role Model for Policy Analysis' (1980) 8 Policy Studies Journal 958, 960.

${ }^{89} \mathrm{HH}$ Koh, 'The Legal Adviser's Duty to Explain' (2016) 41 Yale Journal of International Law 189.

${ }^{90}$ Ibid, 197 (emphasis added).

${ }^{91}$ Ibid, 196 (excluding 'predecisional legal deliberations').
} 
Where the set of reasons to be publicly ventilated in support of a policy decision does not correspond with the legal advice rendered at an earlier stage, involvement in advocacy mode may require instrumental legal interpretation. ${ }^{92}$ States tend to avoid conceding breach of international law, preferring to 'cloak their transgressions in the false colours of existing right'. ${ }^{93}$ In such circumstances, advocacy mode may become an exercise in 'impression management', where the adviser is tasked with presenting some things to their audiences while hiding others 'backstage'. ${ }^{94}$ Advisers who, before the decision, had been tasked with preserving the 'boundaries of permissible executive branch action' may become involved in 'moving, manipulating or simply ignoring these boundaries' after a decision is reached. ${ }^{95}$

Entry into advocacy mode can curb the adviser's ability to work from within, the redeeming feature (according to Hirschman) of continued loyal service where public goods such as foreign policy are at stake. Incentives frequently exist for advisers to demonstrate that they are part of the 'band of brothers and not simply pencil-pushers or nay-sayers'. ${ }^{96}$ Acquiescing in spin-doctoring, even from the sidelines, can catalyse a perception that the adviser has entered a 'culture of reticence, complacence and complicity'. ${ }^{97}$ Engagement in advocacy mode today, rationalised on the basis that one may have the opportunity to work from within tomorrow, is a cautionary tale about how advisers can become accomplices, tied to 'appalling ventures for remarkably long periods'. ${ }^{98}$

\section{B. Wilmshurst: flight as fight}

Wilmshurst requested early retirement the day after the release of the Attorney General's Written Answer. One might surmise that the misleading effect of the supporting 'Foreign Office' memorandum was the final straw for her. Wilmshurst's letter accordingly commenced with a clear reiteration of her earlier advice: 'I cannot ... go along with advice-within the Office or to the public or Parliament - which asserts the legitimacy of military action without ... [a further Security Council] resolution'. ${ }^{99}$ She went on to argue that the approach adopted by proponents of the revival argument in the Written Answer and 'Foreign Office' memorandum was 'detrimental to the international order and the rule of law'. 100

Resignation letters can be an effective means to publicly identify exit as an expression of resistance, creating a rupture in an 'otherwise perfectly planned, smoothly executed narrative of the powerful'. ${ }^{101}$ In her letter, Wilmshurst countered the revival argument with a legal explanation that articulated the interpretation preferred by FCO legal advisers. Although it evidenced emphatic opposition to the government's legal explanation, Wilmshurst sent her letter to her line manager rather than making it publicly available. While the motivation for her departure may have been broadly explicable to well-informed Whitehall watchers,

\footnotetext{
92 R Falk, 'The Place of Policy in International Law' (1972) 2 Georgia Journal of International and Comparative Law 29, 30 (describing advisers as assuming the role of 'functionaries and technicians who provide appropriate legal argumentation to buttress governmental positions').

${ }^{93}$ A Cassese, 'The Role of Legal Advisers in Ensuring that Foreign Policy Conforms to International Legal Standards' (1992) 14 Michigan Journal of International Law 139, 160.

${ }^{94}$ S Hilgartner, Science on Stage: Expert Advice as Public Drama (Stanford University Press 2000).

95 N Spaulding, 'Independence and Experimentalism in the Department of Justice' (2011) 63 Stanford Law Review 409, 409.

${ }^{96}$ D Luban, 'That the Laws Be Faithfully Executed: The Perils of the Government Legal Advisor' (2012) 39 Ohio Northern University Law Review 1043, 1053-54.

97 T Franck, 'An Outsider Looks at Foreign Office Culture' (2005) 23 Wisconsin International Law Journal 4, 5.

98 B Williams, 'Politics and Moral Character' in Moral Luck (CUP 1981) 54, 57.

${ }^{99}$ Wilmshurst resignation letter.

100 Ibid.

${ }^{101}$ M Potter, The Last Goodbye: A History of the World in Resignation Letters (Constable 2015) xii.
} 
Wilmshurst's exit was not accompanied by contemporaneous public voice. This accords both with the ethical duties of lawyers not to disclose advice given to clients, and the obligations of former officials not to speak publicly about sensitive aspects of their work unless authorised to do so

Nevertheless, the contents of Wilmshurst's letter have had a protracted and impactful shelf-life. The public disclosure of Wilmshurst's letter in 2005 revealed - for the first timethe existence of the Attorney General's earlier advice, which considered that the 'safest legal course' would be to procure a further Security Council resolution. Thanks to Wilmshurst's letter, the Attorney General's interpretive U-turn became a cause célèbre in the lead-up to that year's General Election. ${ }^{102}$ When her letter was made available, Wilmshurst's reference to the crime of aggression served as a timely reminder of the jus contra bellum telos of the UN Charter, asserting an 'anti-war politics' that is too often superseded by a focus on the conduct of conflict. ${ }^{103}$ Although the English courts had held in the interim that aggression did not constitute a crime under domestic law, ${ }^{104}$ Wilmshurst's invocation of aggression continued to linger over the reputation and legacy of the Blair government, as well as constituting a message in a bottle for the future trajectory of international criminal justice.

\section{Special responsibility after the decision}

Rather than being a purely personal conscience call, the choice to stay or go confers distinct capacities for the realisation of the adviser's special responsibility after the decision by conditioning the adviser's involvement in subsequent legal explanation. The special responsibility has implications for the type of arguments that should be regarded as acceptable justifications for government action, not only in internal decision-making but alsosignificantly_ in 'advocacy on behalf of a government policy'. ${ }^{105}$ A former legal adviser at the US State Department argued that where government lawyers 'exceed the bounds of honest and responsible argument - functioning purely as apologists or 'hired guns'- they betray not only their responsibilities but their vocation'. ${ }^{106}$

The demands of advocacy mode while remaining in post may lead to a fundamental tension with the adviser's special responsibility. In advocacy mode, the adviser may be required to contribute to formulating sales pitches in a legal idiom rather than sober assessments of risks and challenges, giving rise to a perception that their special responsibility ceased at the moment of decision. On the other hand, the adviser who combines exit with voice can help expose interpretive distortions generated in advocacy mode, upholding their ongoing fealty to the international law project.

The reasons Wilmshurst gave for her departure may not have had a direct causal impact on decision-making, but have undoubtedly had a reverberating justificatory effect. ${ }^{107}$ Although the UK government argued that their proposed use of force was legally permissible, the broad

\footnotetext{
102 J Strong, Public Opinion, Legitimacy and Tony Blair's War in Iraq (Routledge 2017) 112.

${ }^{103}$ S Moyn, 'From Antiwar Politics to Antitorture Politics' in A Sarat, L Douglas and MM Umphrey (eds), Law and War (Stanford University Press 2014) 154.

${ }^{104} R v$ Jones (Margaret) [2007] 1 AC 136; $R$ (Al Rabbat) $v$ Westminster Magistrates Court [2017] EWHC 1969 (Admin).

${ }^{105}$ A Byrnes, "'The Law was Warful”: The Iraq War and the Role of International Lawyers in the Domestic Reception of International Law' in H Charlesworth et al (eds), The Fluid State: International Law and National Legal Systems (Federation Press 2005) 229, 237-8.

${ }^{106}$ R Bilder, 'On Being an International Lawyer' (2006) 3 Loyola University Chicago International Law Review $135,145$.

${ }^{107}$ M Koskenniemi, 'The Place of Law in Collective Security' (1996) 17 Michigan Journal of International Law 455 (observing that law's value does not reside in the causal explanation of behaviour, but in the justification process it imports into institutional policy).
} 
consensus amongst states and the international legal community accorded with the view of FCO legal advisers that the system of collective security enshrined in the UN Charter had been debased. An awareness that the force of advice inheres in its justificatory rather than causal properties was on display in the editorial penned by Wilmshurst after the release of the Report. Titled 'We Ignored the Rule of Law-The Result Was Iraq', Wilmshurst concluded: 'Acting contrary to the Charter - as I perceived the government to be doing-would damage the UK's reputation as a state committed to the rule of international law. That was my belief; so it has proved'. ${ }^{108}$ Wilmshurst's approach accorded with her view that, in difficult cases, the adviser should 'reflect a responsibility to the international legal system as a whole, if that system is to be sustainable'. ${ }^{109}$

\section{LEARning Lessons: The Use of ForCE AND THE ForCE OF ADVICE}

'The Dissenters existed: therefore they deserve to be put on record. They cannot be passed over by anyone who is studying British foreign policy in its official form'.

AJP Taylor ${ }^{110}$

In discussing how the adviser's special responsibility might endure after a policy decision is reached, we have moved rather far from the focus of the Report itself. On its face, the Report does not offer overt action guidance for civil servants faced with similar dilemmas in the future. ${ }^{111}$ However, the lessons articulated in the Report, and the analysis of the adviser's special responsibility advanced here, are mutually reinforcing.

While many of the lessons pertaining to pre-conflict strategy and planning were 'largely context-specific', ${ }^{112}$ the Report also set out several lessons of more general application. First, the Report offered some reflections on the US-UK 'special relationship', given that it was a 'determining factor' in the UK's decision-making. ${ }^{113}$ Blair regarded the decision to stand 'shoulder to shoulder' with the US as an 'essential demonstration of solidarity' and in the UK's long-term national interest. ${ }^{114} \mathrm{He}$ considered that the 'objectives the UK identified for a successful strategy' for Iraqi disarmament through the Security Council authorisation regime should not be 'expressed as conditions for its support'. ${ }^{115}$ The Report condemned this pursuit of influence at all costs, observing that the 'exercise of influence is a means to an end', and that ' $\mathrm{i}] \mathrm{f}$ certain measures are identified as prerequisite for success then their importance should be underlined from the start'. ${ }^{116}$

Secondly, the Report considered the process of collective decision-making, concluding that the intervention had not been 'calculated, debated and challenged with the utmost

\footnotetext{
${ }^{108}$ E Wilmshurst, 'We Ignored the Rule of Law-The Result Was Iraq' The Guardian (7 July 2016) <https://www.theguardian.com/commentisfree/2016/jul/07/ignored-rule-law-war-result-was-iraq-un-charterforeign-office-lawyer-2003>.

${ }^{109}$ E Wilmshurst in 'Disciplining the Discipline: Roles and Responsibilities of International Lawyers' (2006) 100 ASIL Proc 449, 449-50.

${ }^{110}$ AJP Taylor, The Troublemakers: Dissent Over Foreign Policy, 1792-1939 (Hamish Hamilton 1957$) 15$.

111 At the time of writing, this is the topic taxing the minds of career officials in the US State Department under President Donald Trump. See WB Wendel, 'Government Lawyers in the Trump Administration' (2017) 69 Hastings Law Journal 275; D Luban, 'The Case Against Serving' (Just Security, 14 November 2016) <https://www.justsecurity.org/34404/case-serving-trump>.

112 Report, Executive Summary, para 826.

${ }_{113}$ Report, vol 6, Section 7, para 351.

${ }^{114}$ Ibid, para 3.

115 Ibid, para 378.

116 Ibid, para 441.
} 
rigour' ${ }^{117}$ It recommended mechanisms to 'probe and challenge the implications of proposals', as well as identify 'wider implications and risks'. ${ }^{118}$ After the release of the Report, Chilcot specifically affirmed the responsibility of civil servants to challenge the administration, encouraging them to 'take their courage in both hands and insist on their right to be heard'. ${ }^{119}$

The Report's lessons on the perils of the US-UK 'special relationship' and the pitfalls of collective decision-making can be bolstered by evaluating the conduct of individuals like Wood and Wilmshurst. In the exercise of their special responsibility before a decision was reached, Wood and Wilmshurst consistently rejected the unilateralism represented by Operation Iraqi Freedom, avoided the siren call of 'group think', ${ }^{120}$ and acted as devil's advocates in foreign policy decision-making. Compared to Blair's pursuit of influence, exemplified by his 'I will be with you, whatever' note to President Bush, ${ }^{121}$ Wood and Wilmshurst sought to uphold the objectives the UK had identified as key to its foreign policy strategy in Iraq: disarmament through the Chapter VII Security Council regime.

The Report's conclusion that the UK's actions had 'undermined the authority of the Security Council' can be read as a strong-albeit indirect-affirmation of Wood's and Wilmshurst's position, which refused to trade off the national interest in a system of collective security at the altar of influence. They were - in the evocative terms of Philip Allott - a 'small voice of the universal within the cacophony of the particular'. ${ }^{122}$

What the Report did not do is offer a view on the circumstances in which it might be appropriate for legal advisers to throw a spanner in the works after an adverse decision is reached, rather than to function dutifully as cogs in the wheel. While stories of brave individuals who said 'no' are at the 'center of our moral life', ${ }^{123}$ the Report's 'civic epistemology' revealed a marked aversion to telling such stories. ${ }^{124}$ At the conclusion of his magnum opus on strategy, Sir Lawrence Freedman - one of the Inquiry committee memberscritiqued a persistent tendency to seek explanations in terms of stories about individuals. ${ }^{125}$ Methodological individualism readily invites the fundamental attribution error, overestimating individual psychological disposition at the expense of adequate consideration of complex institutional contexts. ${ }^{126}$ Rather than focusing on the virtuous character traits of particular individuals, the Report reminds us that the activities of agents take place in structural contexts

\footnotetext{
${ }^{117}$ Chilcot, 'Statement by Sir John Chilcot, 6 July 2016'

<http://webarchive.nationalarchives.gov.uk/20171123123519/http://www.iraqinquiry.org.uk/media/247010/201 6-09-06-sir-john-chilcots-public-statement.pdf>.

118 Report, vol 6, Section 7, para 413.

${ }^{119}$ House of Commons Liaison Committee, 'Follow up to the Chilcot Report' (HC 689), transcript of evidence given by Sir John Chilcot, 2 November 2016, Q50 <https://www.parliament.uk/documents/commonscommittees/liaison/John-Chilcot-oral-evidence.pdf >; House of Commons Public Administration and Constitutional Affairs Committee, 'Lessons Still to Be Learned from the Chilcot Inquiry' (HC 656) (16 March 2017) 22-25 (endorsing a 'culture of challenge' in collective decision-making); House of Commons Foreign Affairs Committee, 'Progress of the Iraq Inquiry' (HC 1027), transcript of evidence given by Sir John Chilcot, 4 February 2015 ,

<http://data.parliament.uk/writtenevidence/committeeevidence.svc/evidencedocument/foreign-affairscommittee/progress-of-the-iraq-inquiry/oral/17950.html>.

${ }^{120}$ IL Janis, Groupthink: Psychological Studies of Policy Decisions and Fiascoes (Houghton Mifflin 1982).

${ }^{121}$ Report, vol 6, Section 7, para 86.

122 P Allott, 'The International Lawyer in Government Service: Ontology and Deontology' (2005) 23 Wisconsin International Law Journal 13, 23.

123 S Sontag, 'Of Courage and Resistance' The Nation (17 April 2003) <https://www.thenation.com/article/courage-and-resistance>.

${ }^{124}$ S Jasanoff, 'Restoring Reason: Causal Narratives and Political Culture' in Science and Public Reason

(Routledge 2012) 59, 61.

${ }^{125}$ L Freedman, Strategy: A History (OUP 2013) 615.

${ }^{126}$ BS Chimni, International Law and World Order: A Critique of Contemporary Approaches (2nd edn, CUP 2016) 279.
} 
that both enable and restrict their practices. ${ }^{127}$ In so doing, the Report helps lay the groundwork to think through, in more systemic terms, the 'capacity to resist'. ${ }^{28}$

An additional lesson put forward in this article is that discharge of the government legal adviser's special responsibility after a policy decision may require something more than remaining in post if the adviser considers the position in advocacy mode to be legally wrong, and the legal explanation given to be misleading. Explicitly commending the intransigence of individuals like Wilmshurst in the Report would have been one way of 'encouraging the best in our public servants, now and in the future', ${ }^{129}$ and might have empowered those who are minded to resist unlawful government conduct in the future.

While Wilmshurst's departure is an episode that engenders widespread veneration amongst public international lawyers, we must resist reproducing Panglossian portrayals of those who stand 'tall for the rule of law', ${ }^{130}$ without an accompanying sensitivity to the consequences of that juridical commitment in specific situations. The hazards of 'valorising the currency' was expressed by several scholars who argued that the Iraq War was unlawful, ${ }^{131}$ but who later maintained that there should be careful reflection on why 'all it would have taken to make the war legal was Security Council authorisation'. ${ }^{132}$ Moreover, the assumption that an allegiance to Security Council authority serves counter-hegemonic ends is an 'unwarranted lionisation of the UN project', ${ }^{133}$ neglecting to scrutinise the ways that hegemonic power can be exercised at the multilateral level through, rather than against, international law. ${ }^{134}$

It is here that individual conscience might come back in, assuming a residual role that is distinct from the special responsibility of international lawyers, in recognition of the fact that a myopic focus on legal technique can short-circuit appropriate moral deliberation. ${ }^{135}$ Conscience may catalyse advisory awareness that a lawful war is not always a prudent one, and that international law is not necessarily on the side of the angels. As advice for advisers, that is surely far from unsatisfactory.

\footnotetext{
127 O Thomas, 'Good Faith and (Dis)honest Mistakes? Learning from Britain's Iraq War Inquiry’ (2017) 37 Politics 371 (analysing how the predilection for juridical individualism leads to a palliative discourse that ignores the rationalities of governance). See also M Windsor, 'Consigliere or Conscience? The Role of the Government Legal Adviser' in J d'Aspremont et al (eds), International Law as a Profession (CUP 2017) 355, 378-81.

${ }^{128}$ H Caygill, On Resistance: A Philosophy of Defiance (Bloomsbury 2015) 157; E Press, 'Moral Courage: A Sociological Perspective' (2018) 55 Society 181.

${ }^{129}$ D Luban, 'Remembering Abu Ghraib (2): Not Company Men and Women' (Just Security, 28 April 2014) <https://www.justsecurity.org/9971/remembering-abu-ghraib-2-company-men-women>. See also R Weisberg, In Praise of Intransigence: The Perils of Flexibility (OUP 2014).

${ }^{130}$ T Franck, 'What Happens Now? The United Nations After Iraq' (2003) 97 AJIL 607, 620.

131 'War Would Be Illegal', The Guardian (7 March 2003) 29.

${ }^{132}$ M Craven, S Marks, G Simpson, and R Wilde, "We are Teachers of International Law" (2004) 17 Leiden Journal of International Law 363, 371, 373.

133 A Rasulov, 'Writing About Empire: Remarks on the Logic of a Discourse' (2010) 23 Leiden Journal of International Law 449, 453.

134 J Alvarez, 'Hegemonic International Law Revisited' (2003) 97 AJIL 873; C Miéville, 'Multilateralism as Terror' (2008) 19 Finnish Yearbook of International Law 63.

${ }^{135}$ D Kennedy, A World of Struggle: How Power, Law and Expertise Shape Global Political Economy (Princeton University Press 2016) 13 (describing how the 'lost opportunity to engage expertise as a doorway to responsible decision rather than as a substitute for ethical reflection and political choice is dramatically on display in the increasing legalization of military conflict').
} 